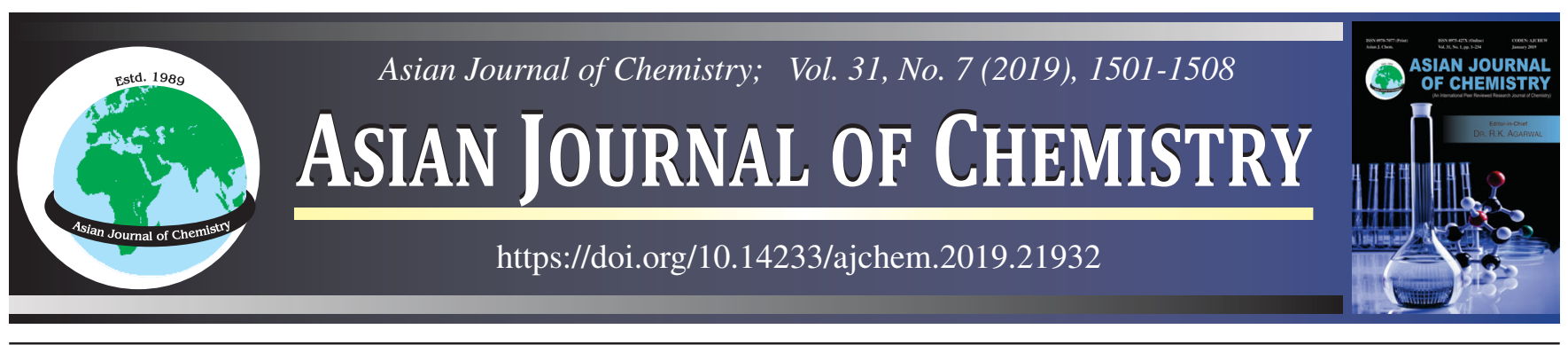

\title{
Evaluation of Equilibrium Isotherms and Kinetic Parameters for the Adsorption of Methyl Orange Dye onto Blue Green Algal Biomass
}

\author{
Surabhi SAgAr and Arshi Rastogi*
}

Department of Chemistry, K.L.D.A.V. (P.G.) College, Roorkee-247667, India

*Corresponding author: E-mail: arshirastogi@gmail.com

Received: 12 January 2019; Accepted: 7 March 2019; Published online: 21 May 2019;

The adsorption of an acidic dye methyl orange onto the dead blue green algal biomass, Oscillatoria species was investigated in a batch mode with respect to contact time, adsorbent dose, $\mathrm{pH}$ and temperature. The functional groups and the surface morphology of $O$ scillatoria species was analyzed by Fourier transform infrared spectroscopy and scanning electron microscopy. Equilibrium isotherms were analyzed by Langmuir, Freundlich, Dubinin-Radushkevich (D-R) and Temkin adsorption models out of which, Langmuir isotherm model was found to be the best fit and exhibited a maximum adsorption capacity of $98.03 \mathrm{mg} / \mathrm{g}$ under the optimized conditions. The pseudo-first | order, pseudo-second order and intraparticle diffusion models were used to describe the kinetic data and the rate constants at different concentrations were evaluated. Kinetics of adsorption was found to follow the pseudo-second order rate equation. The thermodynamic parameters, such as the changes in enthalpy, entropy and Gibbs free energy showed that the adsorption is endothermic, random and spontaneous at high temperature. The adsorbent could be regenerated using $0.1 \mathrm{~mol} / \mathrm{L} \mathrm{HCl}$ solutions, with upto $75 \%$ recovery. The results indicate that Oscillatoria species could be fruitfully employed as effective biomaterial for the removal of dyes from effluents.

Keywords: Oscillatoria species, Methyl orange, Adsorption, Isotherms, Kinetics.

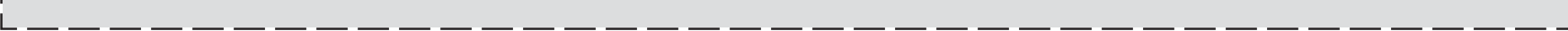

\section{INTRODUCTION}

Large amount of water is being continuously consumed by textile industries at different steps of dyeing, finishing etc. As there is a large consumption of water the pouring up of waste water into the environment is also unavoidable. This waste water from the industries is very rich in colour containing residue of dyes as major effluents. With the increase in the water pollution due to textile waste, the stringent restrictions on the hazardous organic contents of the industrial effluents is also increasing and hence it becomes important to remove these organic pollutants by proper treatment methods before being released to the water course. Generally, the dyes have stability towards light and oxidizing agents and are non-degradable in nature and this makes the selection of suitable method for dye removal complicated [1,2]. Various treatment techniques have been used for the removal of organic as well as inorganic substances from water, such as adsorption $[3,4]$, photocatalytic degradation [5], electrochemical [6], membrane process [7], etc., but among these due to advantages like low cost, high efficiency, easy availability and ability to separate a wide range of chemical compounds in a bulk, adsorption is considered as a relatively superior technique for the removal of dyes $[8,9]$.

The acid dyes are the most widely used dyes in the textile dyeing industries and are considered as obnoxious type of pollutants as they impart colour to water which is not acceptable due to esthetical consideration. Methyl orange is known to be toxic, carcinogenic, mutagenic and teratogenic; hence the removal of this dye from waste water is important before they are mixed up with unpolluted natural water resources. After going through the literature, we have come to a conclusion that limited number of studies has been done on the removal of methyl orange dye from aqueous solutions. The adsorbents used earlier for removal of methyl orange were calcined lapindo volcanic mud [10], waste mycelium of Streptomyces fradie bacteria [11] and brown macro alga Stoechospermum marginatum $[12,13]$.

Researchers have successfully employed adsorbents like activated carbon prepared from agricultural wastes [14], activated

This is an open access journal, and articles are distributed under the terms of the Creative Commons Attribution-NonCommercial-ShareAlike 4.0 (CC BY-NC-SA 4.0) International License which allows readers to freely read, download, copy, distribute, print, search, or link to the full texts of its articles and to use them for any other lawful non-commercial purpose as long as the original source is duly acknowledged. 
globe Artichoke leaves [15], cresson (Lepidium sativum) seeds [16], alginate/sericin composite beads [17] and biomaterials like chitin, chitosan, yeast, fungi and bacteria [9] in order to concentrate and remove dyes from solutions. However, these low cost adsorbents have low adsorption capacities. Algae have been found as potential adsorbents because of their special surface properties. Their cell wall offers a host of functional groups like carboxyl, sulphate, phosphate, amino and imidazoles associated with polysaccharides alginic acid and proteins for binding various pollutants [18]. Our lab has also earlier used algae as adsorbent for the removal of dyes [19,20]. In our continued interest, we have used abundantly available blue green alga Oscillatoria species for the removal of acid dye methyl orange from synthetic solutions. Oscillatoria is a genus of filamentous cyanobacterium of family cyanophyceae, i.e., found floating on fresh water ponds, on wet rocks or on soil.

Thus, the objective of the present work is to evaluate the adsorption potential of a natural adsorbent Oscillatoria species for the acid dye methyl orange from synthetic solutions. After the characterization of the test alga by SEM, FTIR and elemental analysis, the various operational parameters like contact time, adsorbent dose, $\mathrm{pH}$ and temperature were optimized for further studies. Various adsorption isotherms were used to fit the equilibrium data. Kinetic studies were attempted to examine the controlling mechanism of adsorption process. Thermodynamic parameters were also evaluated followed by algal reuse studies.

\section{EXPERIMENTAL}

Technical grade methyl orange of $98 \%$ purity was used without further purification. All other chemicals used in this study were of analytical grade. Doubly distilled water was used throughout the experiments. Measurements of $\mathrm{pH}$ of the solution were carried out on a digital $\mathrm{pH}$ meter (PERFIT, India) and absorbance of samples was recorded using UV-visible spectrophotometer-119 (Systronics India Ltd). The FTIR spectrum of algal biomass was done using $\mathrm{KBr}$ pellets on a Thermo Nicolet FTIR (Germany) within $4000-400 \mathrm{~cm}^{-1}$ ranges. Scanning electron microscopywas performed using ZEISS EVO 40 EP (Cambridge, UK) with analytical software-Quantax 200 instrument. Elemental analyze system Vario MICRO CHNS V3.1.1 (GmbH, Germany) was used to carry out the analysis of carbon, hydrogen, sulphur and nitrogen.

Adsorbent and adsorbate: Oscillatoria species, a blue green algae was used as an adsorbent in this study. Samples of this biomaterial were collected from the fresh water ponds near Roorkee and Haridwar. The adsorbent was washed with tap water and then with distilled water several times to remove extraneous material. After sun drying for 2 days the adsorbent was dried in the oven at $343 \mathrm{~K}$ for $24 \mathrm{~h}$. The dried mass was ground and sieved to the required particle size of $100 \mu \mathrm{m}$ mesh size. The powdered adsorbent was maintained in vacuum desiccators prior to use.

Methyl orange dye used as adsorbate in this study, is an acidic dye having a m.f.: $\mathrm{C}_{14} \mathrm{H}_{14} \mathrm{~N}_{3} \mathrm{NaO}_{3} \mathrm{~S}$, m.w.: $327.33 \mathrm{~g} \mathrm{~mol}^{-1}$ and $\lambda_{\max } 463 \mathrm{~nm}$. The dye stock solution was prepared by dissolving accurately weighed amounts of dye in $1000 \mathrm{~mL}$ distilled water. Synthetic waste water was prepared after diluting the stock solution. Standard curve with excellent correlation $\left(R^{2}=0.992\right)$ was established for different concentrations of the dye solution (from 1 to $10 \mathrm{mg} / \mathrm{L}$ ). The absorbance of dye solutions with known concentrations was measured by a spectrophotometer at wavelength of $463 \mathrm{~nm}$. Distilled water was used as a reference in all the experiments.

Adsorbent characterization: The surface appearance of algal biomass before and after adsorption was studied by SEM. The percentage composition of $\mathrm{C}, \mathrm{H}, \mathrm{N}$ and $\mathrm{S}$ was examined by elemental analysis. Fourier transform infrared spectroscopy was used to identify the nature of surface functional groups on the algal biomass.

Batch studies: Adsorption experiments were performed in batch mode to investigate the effects of various parameters. The effect of contact time (0-160 min), $\mathrm{pH}$ of solution (range 2-12), adsorbent dose (1-10 mg/L) and temperature (298, 308 and $318 \mathrm{~K}$ ) on the adsorption capacity were studied. To obtain adsorption isotherms, the adsorbent was suspended in methyl orange solution at three different temperatures i.e. 298, 308 and $318 \mathrm{~K}$, while the other parameters were kept constant. Kinetic studies of adsorption by algal biomass were also carried out at two different concentrations (100 and $200 \mathrm{ppm}$ ) at 318 $\mathrm{K}$ wherein the extent of adsorption was analyzed at regular time interval.

Desorption studies: The adsorbent used for adsorption of dye from synthetic wastewater was separated from the solution by filtration and then was dried. The dried mass was then allowed to contact with $50 \mathrm{~mL}$ of desorbing agents like $\mathrm{HCl}$ (acid), $\mathrm{NaOH}$ (base) and EDTA (ethylenediaminetetraacetic acid) (chelating agent), respectively, each in $100 \mathrm{~mL}$ conical flask at $318 \mathrm{~K}$ for $100 \mathrm{~min}$, for five consecutive cycles using the same adsorbent. A single cycle sequence consists of adsorption followed by desorption. After each adsorption, the resultant dye loaded algal biomass was filtered and reintroduced into the desorption solvent.

$$
\text { Desorption efficiency }(\%)=\frac{\text { Amount of dye desorbed }}{\text { Amount of dye adsorbed }} \times 100
$$

\section{RESULTS AND DISCUSSION}

Surface characteristics: The algal biomass subjected to elemental analysis showed the composition of $\mathrm{C}, 21.55 \%$; N, $4.15 \%$; H, $2.949 \%$; S, $0.312 \%$. The morphological characteristic of the adsorbent depicts the surface characteristics of the tested material and here the micrograph shows uneven porosity and rough surface of Oscillatoria species (Fig. 1a). The changes in surface morphology of adsorbent after adsorption can be seen in Fig. 1b. It was observed that the uniform porosity of the adsorbent was destroyed due to the accumulation of dye on to the surface of the algal biomass.

To study the surface characteristics of adsorbent, FTIR technique was employed. The FTIR spectrum of Oscillatoria species before adsorption of methyl orange dye (Fig. 2a) shows that the major peak positions are at 3408.27, 2923.11, 1643.29, $1536.22,1089.51,523.63$ and $474 \mathrm{~cm}^{-1}$. The bands at 3408.27 $\mathrm{cm}^{-1}$ are due to $\mathrm{O}-\mathrm{H}$ groups of glucose and $\mathrm{N}-\mathrm{H}$ groups of proteins, while bands at $2923.11 \mathrm{~cm}^{-1}$ is due to carboxylic/phenolic stretching. Other bands at $1643.29,1536.48$ and $1089.51 \mathrm{~cm}^{-1}$ 

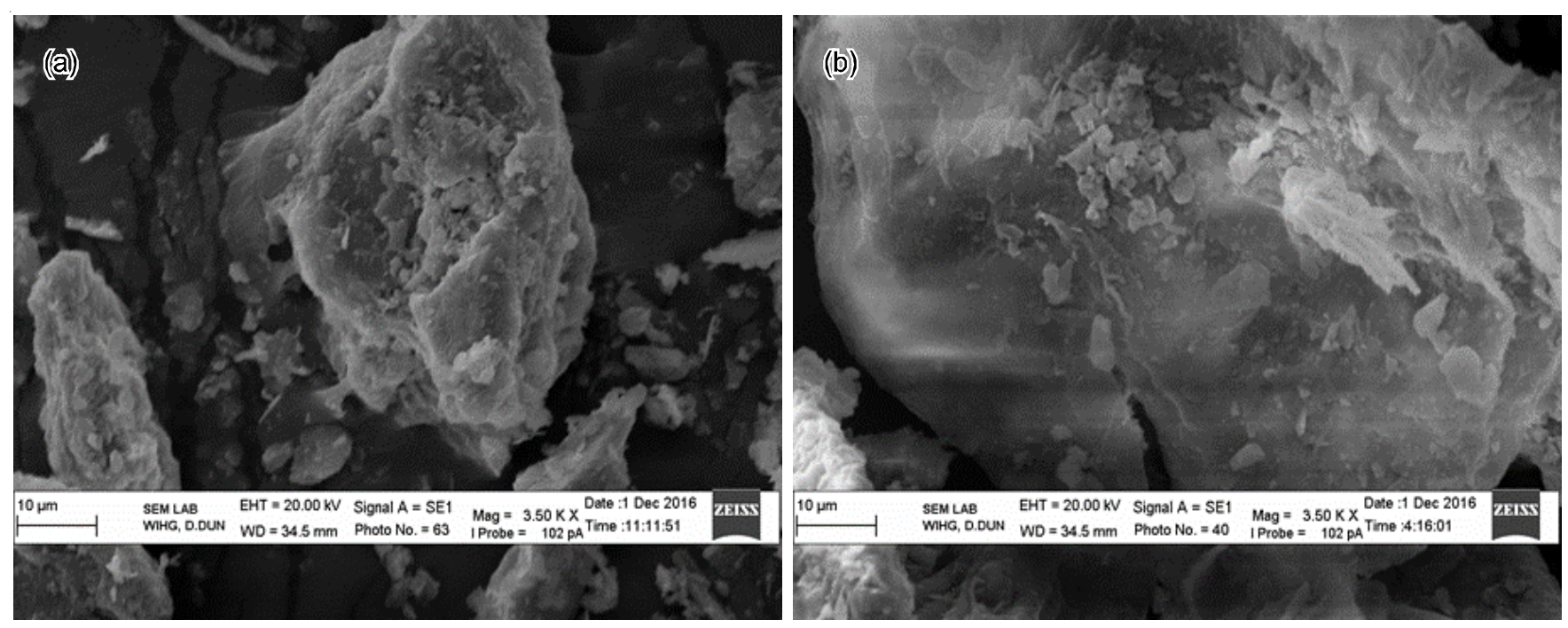

Fig. 1. SEM images for Oscillatoria species (a) before adsorption of methyl orange (b) after adsorption of methyl orange dye
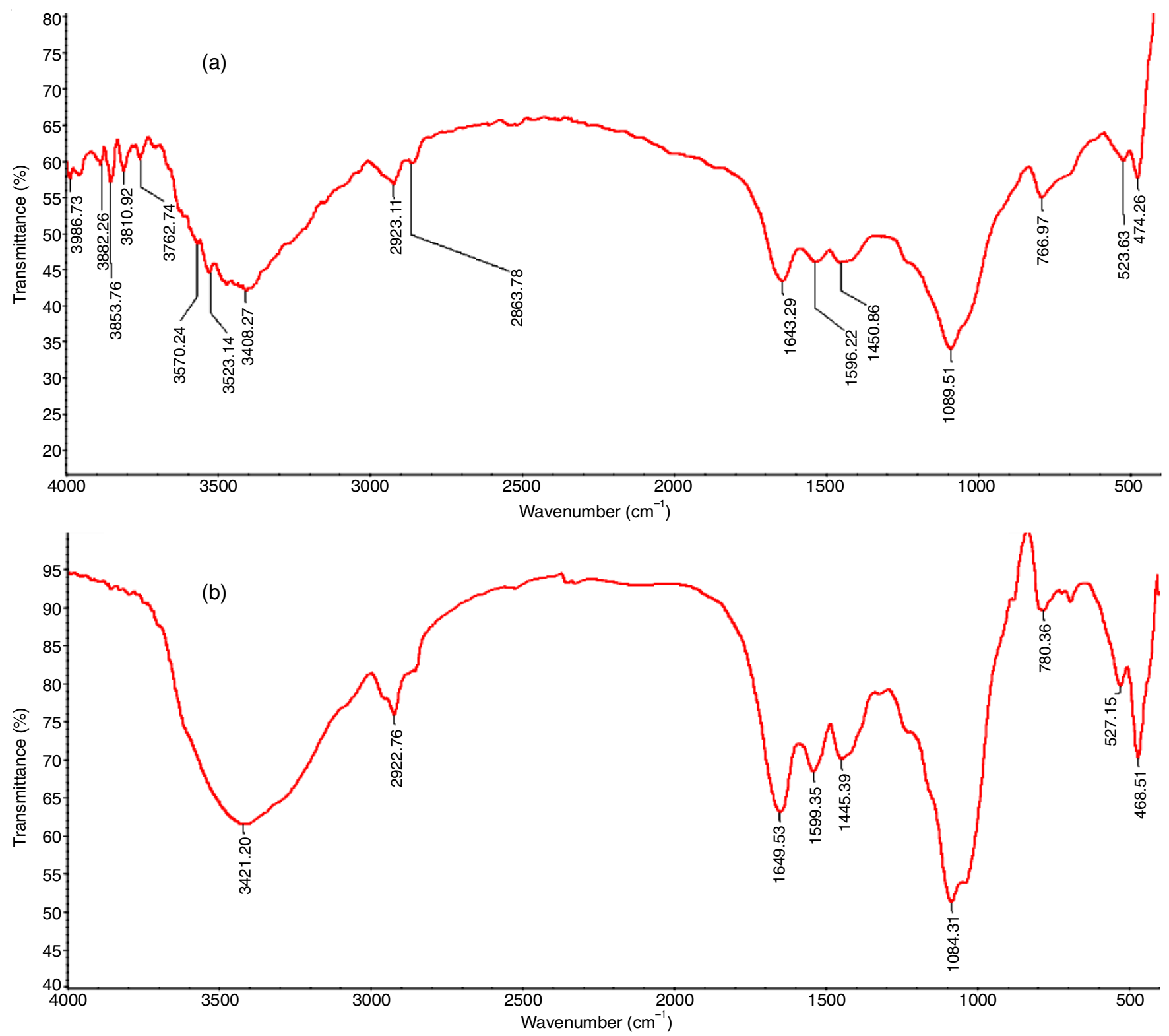

Fig. 2. FTIR spectra of Oscillatoria species (a) before adsorption of methyl orange (b) after adsorption of methyl orange dye 
reflect the carbonyl group stretching, amide band of protein peptide and $\mathrm{C}-\mathrm{N}$ bending, respectively. Moreover, some bands at 523.63 and $474 \mathrm{~cm}^{-1}$ correspond to finger print region mainly due to the phosphate group [18]. After the adsorption of methyl orange dye, the major peaks observed in Fig. 2a were found to be shifted to $3421.20,2922.78,1649.53,1539.35,1084.31$ and $527.15 \mathrm{~cm}^{-1}$ (Fig. 2b), respectively indicating the presence of carboxylic, amino, amide and hydroxyl functional groups on the algal cell wall.

Adsorption studies: Adsorption of methyl orange by algal biomass was studied as a function of contact time, adsorbent dose, $\mathrm{pH}$ and temperature. Each experiment was conducted in triplicate and mean value of data were reported. Since standard deviation never exceeded $\pm 1.5 \%$, the error bars were not shown in the figures. The adsorption capacity was calculated using mass balance equation given as follows.

$$
\mathrm{q}_{\mathrm{e}}=\frac{\left(\mathrm{C}_{\mathrm{o}}-\mathrm{C}_{\mathrm{e}}\right) \mathrm{V}}{\mathrm{M}}
$$

where $\mathrm{q}_{\mathrm{e}}$ is the adsorption capacity of algae $(\mathrm{mg} / \mathrm{g}), \mathrm{C}_{\mathrm{o}}$ and $\mathrm{C}_{\mathrm{e}}$ are the initial and the equilibrium concentration of dye $(\mathrm{mg} / \mathrm{L})$, $\mathrm{V}$ is the volume of reaction mixture $(\mathrm{L})$ and $\mathrm{M}$ is the mass of adsorbent used (g).

Impact of contact time and concentration: Fig. 3 shows the effect of contact time on the extent of adsorption of methyl orange on the algal biomass at four different initial concentrations at $\mathrm{pH} 4$ and temperature $318 \mathrm{~K}$. The curves are single, smooth and continuous, leading to saturation, suggesting the possible monolayer coverage of the dyes on the adsorbent surface. The initial rapid phase may involve physical adsorption at the cell surface, until it reached the equilibrium point (80 min). The slower phase after equilibrium may involve other mechanism such as complexation and saturation of binding sites [21]. As shown in the figure the algal biomass does not show any significant adsorption at low dye concentration.

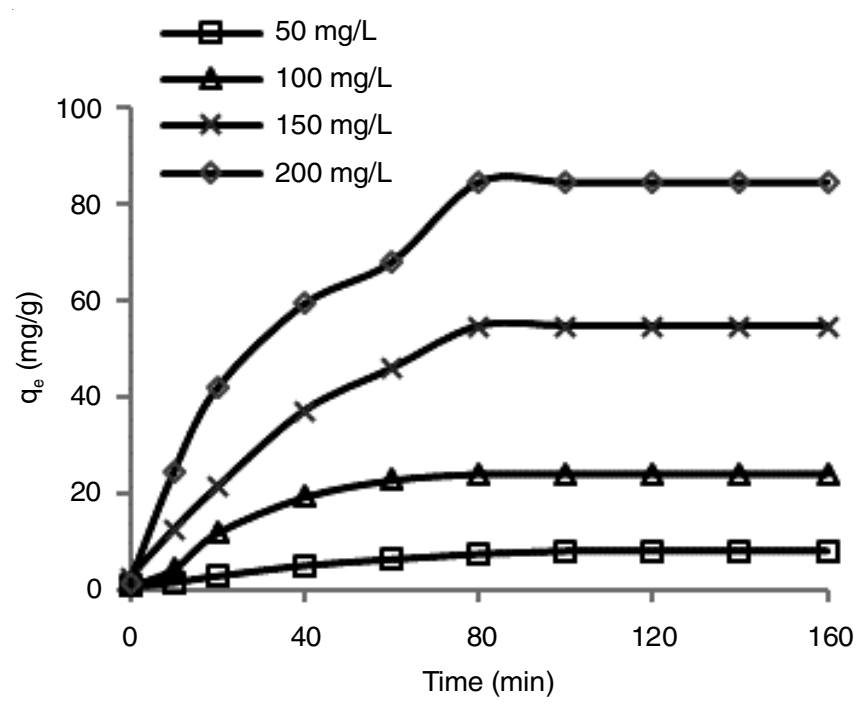

Fig. 3. Impact of contact time on methyl orange dye

Impact of adsorbent dosage: The effect of adsorbent dose on methyl orange removal was evaluated at ten different values of this operating parameter in the range of $1-10 \mathrm{~g} / \mathrm{L}$, while the $\mathrm{pH}$, temperature, initial dye concentration and contact time were kept at optimized conditions. As shown in the Fig. 4, the maximum adsorption capacity of the dye reached equilibrium at $5 \mathrm{~g} / \mathrm{L}$. Such behaviour is related to the increase in the number of active sites available for dye adsorption is in agreement with previous observations on methyl orange by different adsorbents such as de-oiled soya [12] and chitosan [22].

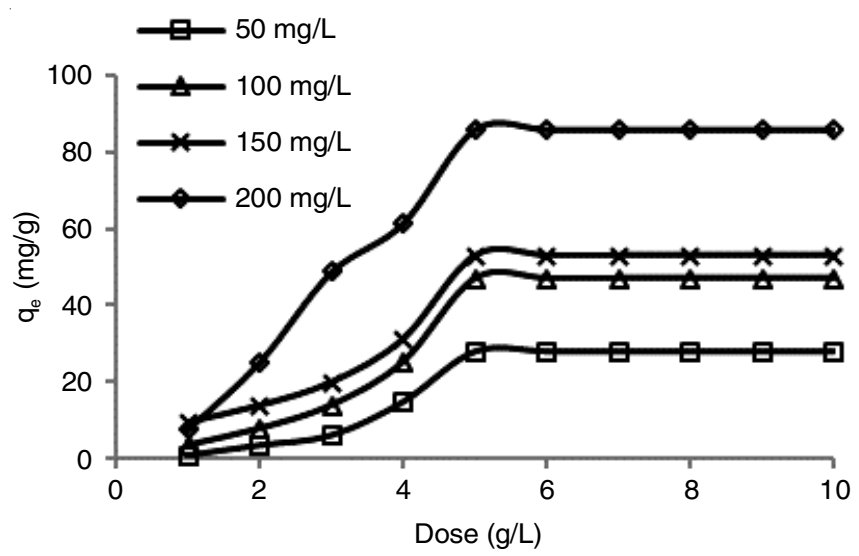

Fig. 4. Impact of adsorbent dose on methyl orange dye

Impact of pH: The effect of initial $\mathrm{pH}$ on the adsorption of methyl orange is shown in Fig. 5. The adsorption capacity increases when the $\mathrm{pH}$ is decreased. Maximum adsorption of acid dyes occurs at acidic $\mathrm{pH}(\mathrm{pH} 4)$. Oscillatoria species is comprised of various functional groups, such as amine, hydroxyl and carbonyl groups which are affected by $\mathrm{pH}$ of the solutions. It seems the dominant mechanism of the adsorption is electrostatic attraction. The electrostatic attraction and the ionic property of algal biomass play an important role in dye adsorption at various $\mathrm{pH}$ values. At lower $\mathrm{pH}$ a considerable high electrostatic attraction exist between positively charged surfaces of the adsorbent due to ionization and negatively charged anionic dye molecules. As the $\mathrm{pH}$ of the system increases, the number of the negatively charged sites also increases. A negatively charged site of the adsorbent does not favour the adsorption of anionic dyes due to the electrostatic repulsion [23]. Thus the effective $\mathrm{pH}$ was 4 and it was used in further studies. Similar results of $\mathrm{pH}$ effects were also reported for the adsorption of chitosan [22] and Humicola fuscoastra [24].

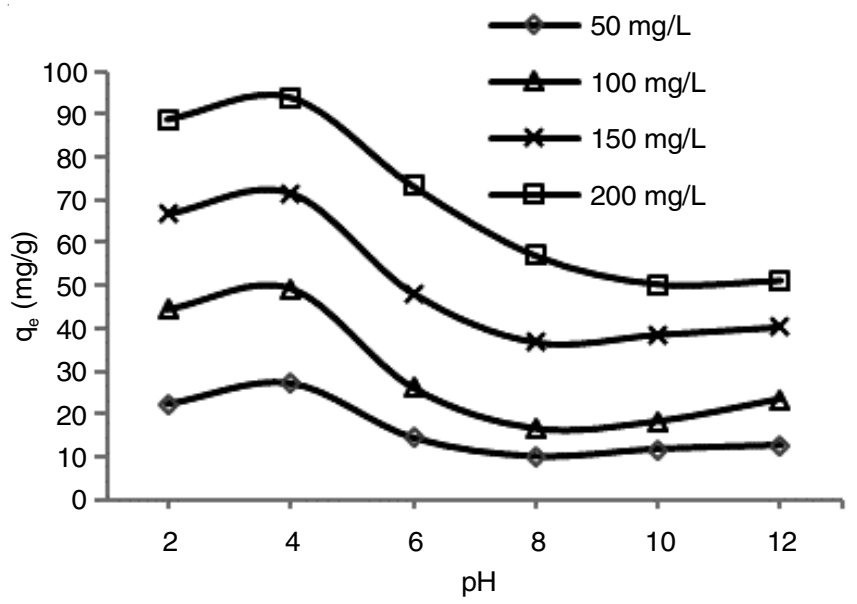

Fig. 5. Impact of $\mathrm{pH}$ on methyl orange dye 
Impact of temperature: The effect of temperature on dye adsorption on algal biomass was investigated at three different temperatures, namely 298,308 and $318 \mathrm{~K}$. When the temperature was increased from 298 to $318 \mathrm{~K}$, the adsorption capacity of the adsorbent progressively increased from 55.70 to 83.26 $\mathrm{mg} / \mathrm{g}$ (Fig. 6), thereby suggesting that the dye adsorption is an endothermic process. The increase in adsorption of dye with an increase in temperature may be attributed to an increased number of active sites on adsorbent surface, reduction of boundary layer thickness of the adsorbent and the greater dissociability of functional groups present on adsorbent surface able to link to dye. Similar increase in adsorption capacity with temperature was reported for removal of acid orange 7 dye by soil [25] and of acid blue 25, acid orange and acid black dyes by Stoechospermum marginatum [13].

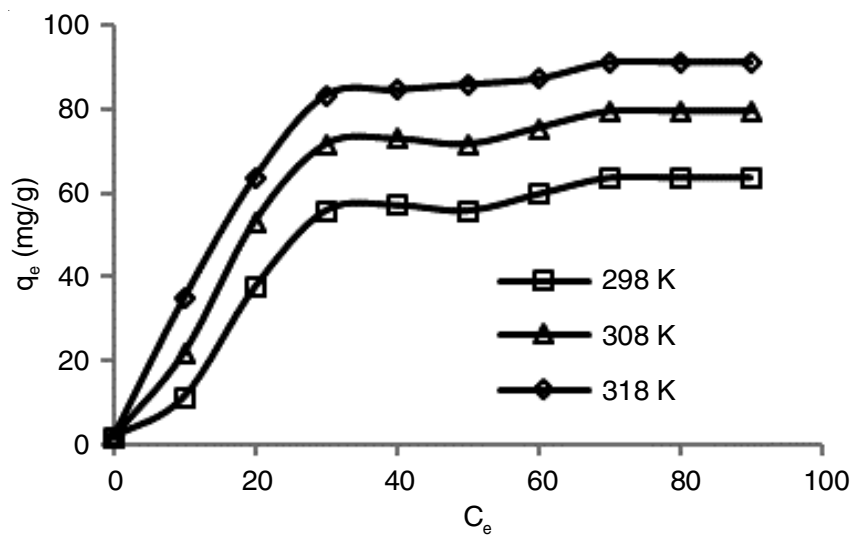

Fig. 6. Impact of temperature on methyl orange dye

Adsorption isotherms: To optimize the design of an adsorption system for the adsorption of adsorbent, it is important to establish the most appropriate correlation for the equilibrium curves. Various isotherm equations like Langmuir, Freundlich, Dubinin-Radushkevich (D-R) and Temkin adsorption isotherms [26-29] were tested in this work. In the Langmuir theory, the basic assumption is that the adsorption takes place at specific homogeneous sites within the adsorbent. It is assumed that once a dye molecule occupies a site, no further adsorption can take place at that site. Theoretically, therefore, a saturation value is reached beyond which no further adsorption can take place. This equation can be written as follows:

$$
\frac{1}{\mathrm{q}_{\mathrm{e}}}=\frac{1}{\mathrm{Q}_{\mathrm{o}}}+\frac{1}{\mathrm{bQ}_{\mathrm{o}} \mathrm{C}_{\mathrm{e}}}
$$

where $\mathrm{q}_{\mathrm{e}}$ is the amount adsorbed $(\mathrm{mg} / \mathrm{g}), \mathrm{C}_{\mathrm{e}}$ is the equilibrium dye concentration of adsorbate $(\mathrm{mg} / \mathrm{L}), \mathrm{Q}_{\mathrm{o}}$ is the Langmuir constant related to maximum monolayer adsorption capacity $(\mathrm{mg} / \mathrm{g})$ and $\mathrm{b}$ relates to the affinity of the adsorbate for the binding sites (expressed in $\mathrm{L} / \mathrm{mg}$ ). By plotting a graph of $1 / \mathrm{q}_{\mathrm{e}}$ versus $1 / \mathrm{C}_{\mathrm{e}}$, a straight line with slope $1 / \mathrm{bQ}_{\mathrm{o}}$ is obtained which shows that the adsorption of methyl orange follows Langmuir isotherm. Langmuir constants are calculated and values of these constants at different temperatures are given in Table-1.

Dimensionless separation factor, $\mathrm{R}_{\mathrm{L}}$, can be calculated from Langmuir constant, $b$, as:

$$
\mathrm{R}_{\mathrm{L}}=\frac{1}{1+\mathrm{bC}_{\mathrm{o}}}
$$

TABLE-1

VARIOUS ADSORPTION ISOTHERM CONSTANTS AND THERMODYNAMIC PARAMETERS FOR THE ADSORPTION OF METHYL ORANGE DYE ONTO Oscillatoria

\begin{tabular}{|c|c|c|c|}
\hline Isotherm parameters & $298 \mathrm{~K}$ & $308 \mathrm{~K}$ & $318 \mathrm{~K}$ \\
\hline \multicolumn{4}{|c|}{ Langmuir isotherm } \\
\hline $\mathrm{B}(\mathrm{L} / \mathrm{mg})$ & 0.4827 & 0.5558 & 0.693 \\
\hline $\mathrm{q}_{\mathrm{e}}(\mathrm{mg} / \mathrm{g})$ & 86.95 & 92.59 & 98.03 \\
\hline $\mathrm{R}^{2}$ & 0.986 & 0.991 & 0.997 \\
\hline \multicolumn{4}{|c|}{ Thermodynamic parameters } \\
\hline$\Delta \mathrm{G}^{\circ}$ & -23.956 & -25.117 & -26.302 \\
\hline$\Delta \mathrm{S}^{\circ}$ & 0.1172 & 0.1171 & 0.1174 \\
\hline$\Delta \mathrm{H}^{\circ *}$ & 10.972 & & \\
\hline \multicolumn{4}{|c|}{ Freundlich isotherm } \\
\hline $\mathrm{N}$ & 2.1208 & 2.860 & 3.279 \\
\hline $\mathrm{K}_{\mathrm{F}}(\mathrm{mg} / \mathrm{g})$ & 13.043 & 23.231 & 33.647 \\
\hline $\mathrm{R}^{2}$ & 0.9553 & 0.934 & 0.934 \\
\hline \multicolumn{4}{|c|}{ Dubinin and Radushkevich isotherm } \\
\hline $\mathrm{q}_{\mathrm{m}}(\mathrm{mg} / \mathrm{g})$ & 0.7893 & 0.9934 & 0.9754 \\
\hline $\mathrm{E}(\mathrm{kJ} / \mathrm{mol})$ & 64.655 & 74.905 & 80.780 \\
\hline $\mathrm{R}^{2}$ & 0.905 & 0.946 & 0.947 \\
\hline \multicolumn{4}{|c|}{ Temkin isotherm } \\
\hline $\mathrm{A}_{\mathrm{T}}$ & 0.7893 & 0.9934 & 0.9754 \\
\hline $\mathrm{b}_{\mathrm{T}}$ & 64.655 & 74.905 & 80.780 \\
\hline $\mathrm{R}^{2}$ & 0.905 & 0.946 & 0.947 \\
\hline \multicolumn{4}{|c|}{ Dimensionless separation factor } \\
\hline $\mathrm{R}_{\mathrm{L}}$ & 0.010 & 0.008 & 0.725 \\
\hline
\end{tabular}
SPECIES AT THREE DIFFERENT TEMPERATURES

The value of $R_{L}$ was computed at different temperatures. The $R_{L}$ values indicate the type of isotherm to be unfavourable $\left(R_{L}>1\right)$, linear $\left(R_{L}=1\right)$, favourable $\left(0<R_{L}<1\right)$ and irreversible $\left(R_{L}=0\right)$. In this study, value of $R_{L}$ was found in the range of $0.010-0.725$, indicating that the adsorption process is favourable [30] for the adsorption of methyl orange dye under the conditions used in this work.

The Freundlich isotherm is derived by assuming a heterogeneous surface with a non-uniform distribution of heat of adsorption over the surface thus allowing multi-layer adsorption. It can be expressed by:

$$
\ln \mathrm{q}_{\mathrm{e}}=\ln \mathrm{K}_{\mathrm{F}}+\frac{1}{\mathrm{n}} \ln \mathrm{C}_{\mathrm{e}}
$$

where $\mathrm{K}_{\mathrm{F}}$ is a Freundlich constant $\left(\mathrm{mg}^{1-1 / n} \mathrm{~L}^{1 / n} \mathrm{~g}^{-1}\right)$ and $\mathrm{n}$ is the adsorption intensity. The plot between $\ln \mathrm{q}_{\mathrm{e}}$ versus $\ln \mathrm{C}_{\mathrm{e}}$ was drawn and the intercept and slope were used to calculate the value of $\mathrm{K}_{\mathrm{F}}$ and $\mathrm{n} .1 / \mathrm{n}$ values indicate the type of isotherm to be irreversible $(1 / \mathrm{n}=0)$, favourable $(0<1 / \mathrm{n}<1)$, unfavourable $(1 / \mathrm{n}>1)$ [31].

The Dubinin and Radushkevich (D-R) isotherm was chosen to calculate the porosity apparent free energy. This isotherm does not assume a homogeneous surface or constant adsorption potential but related to the porous structure of the adsorbent. The linear form of $\mathrm{D}-\mathrm{R}$ isotherm equation is given as:

$$
\begin{aligned}
& \ln \mathrm{q}_{\mathrm{e}}=\ln \mathrm{q}_{\mathrm{m}}-\beta \varepsilon^{2} \\
& \varepsilon=\mathrm{RT} \ln \left(1+\frac{1}{\mathrm{C}_{\mathrm{e}}}\right)
\end{aligned}
$$

where $\mathrm{q}_{\mathrm{m}}$ is maximum adsorption capacity $(\mathrm{mg} / \mathrm{g}), \beta$ is constant related to adsorption energy $\left(\mathrm{mol}^{2} \mathrm{k} \mathrm{J}^{-2}\right), \varepsilon$ is a Polanyi potential, 
$\mathrm{R}$ is the gas constant $\left(8.314 \mathrm{~J} \mathrm{~mol}^{-1} \mathrm{~K}^{-1}\right)$, T is temperature $(\mathrm{K})$. The mean adsorption energy can be calculated from formula:

$$
\mathrm{E}=\frac{1}{\sqrt{2 \beta}}
$$

If the value of $\mathrm{E}$ falls between 8 and $16 \mathrm{~kJ} / \mathrm{mol}$, then the adsorption process is chemically controlled and if the value of $\mathrm{E}$ is $<8 \mathrm{~kJ} / \mathrm{mol}$ then it progresses physically [32]. As shown in Table-1, the calculated value of mean energy was found to be less than $8 \mathrm{~kJ} / \mathrm{mol}$, indicating the adsorption of methyl orange on to Oscillatoria species to be controlled and physical process.

In order to find certain indirect adsorbate-adsorbent interactions on the dye adsorption and that the fall in the heat of adsorption is linear rather than logarithmic, Temkin isotherm was modelled. Temkin model is given by:

$$
\mathrm{q}_{\mathrm{e}}=\frac{\mathrm{RT}}{\mathrm{b}_{\mathrm{T}}} \ln \left(\mathrm{A}_{\mathrm{T}} \mathrm{C}_{\mathrm{e}}\right)
$$

where $\mathrm{R}$ is the gas constant, $\mathrm{T}$ is the absolute temperature in Kelvin. The constants $b_{\mathrm{T}}\left(\mathrm{g} \mathrm{kg} \mathrm{mg}^{-1} \mathrm{~mol}^{-1}\right)$ and $\mathrm{A}_{\mathrm{T}}\left(\mathrm{L} \mathrm{mg}^{-1}\right)$ associated with the heat of adsorption were calculated from slope and intercept of $\mathrm{q}_{\mathrm{e}}$ versus $\ln \mathrm{C}_{\mathrm{e}}$.

The value of $\mathrm{R}^{2}$ (goodness of fit criterion) computed by linear regression for all the investigated types of isotherms are presented in Table-1. Table-1 indicates that the Langmuir isotherm is the most appropriate isotherm to describe the equilibrium behaviour of acid dye [methyl orange] removal by Oscillatoria species.

Thermodynamic parameters: To investigate the thermodynamics of an acid dye methyl orange, adsorption onto Oscillatoria species, the main thermodynamic parameters such as standard changes in free energy $\left(\Delta \mathrm{G}^{\circ}, \mathrm{kJ} / \mathrm{mol}\right)$, enthalpy changes $\left(\Delta \mathrm{H}^{\circ}, \mathrm{kJ} / \mathrm{mol}\right)$ and entropy changes $\left(\Delta \mathrm{S}^{\circ}, \mathrm{kJ} / \mathrm{mol} / \mathrm{K}\right)$ were calculated at three different temperatures $(298,308,318$ $\mathrm{K})$ using the following equations:

$$
\begin{gathered}
\Delta \mathrm{G}^{\circ}=\mathrm{RT} \ln \mathrm{b} \\
\ln \left(\frac{\mathrm{b}_{2}}{\mathrm{~b}_{1}}\right)=-\frac{\Delta \mathrm{H}_{\mathrm{o}}}{\mathrm{R}}\left(\frac{1}{\mathrm{~T}_{2}}-\frac{1}{\mathrm{~T}_{1}}\right) \\
\Delta \mathrm{G}^{\circ}=\Delta \mathrm{H}^{\circ}-\mathrm{T} \Delta \mathrm{S}^{\circ}
\end{gathered}
$$

Table-1 represents the values of $\Delta \mathrm{G}^{\circ}, \Delta \mathrm{H}^{\circ}$ and $\Delta \mathrm{S}^{\circ}$ for the adsorption of methyl orange dye onto Oscillatoria species. The negative value of $\Delta \mathrm{G}^{\circ}$ confirms the thermodynamic feasibility and spontaneity of the process whereas the positive value of $\Delta \mathrm{H}^{\circ}$ indicates the endothermic nature of dyes adsorption that is already evidenced by the increase in adsorption capacity with temperature. The positive value of $\Delta \mathrm{S}^{\circ}$ reflects the increased randomness at the solid/solution interface during the process.
These results are quantitatively similar to those obtained by other researchers for the removal of similar acid dyes by different adsorbents. Daneshwar et al. [13] have reported the negative value of $\Delta \mathrm{G}^{\circ}$ and the positive value of $\Delta \mathrm{H}^{\circ}$ and $\Delta \mathrm{S}^{\circ}$ for the removal of acid blue 25 , acid orange 7 and acid black 1 by brown macro alga Stoechospermum marginatum.

Adsorption kinetics: The principle behind the adsorption kinetics involves the search for a best model that well represents the experimental data. Several models are available to understand the mechanism of solute adsorption on an adsorbent. For examination of the controlling mechanism of adsorption process, such as chemical reaction and diffusion control, simplest kinetics models that are used to test the experimental data were pseudo-first order, pseudo-second order and intraparticle diffusion model [33-35].

Pseudo-first-order equation is generally represented as follows:

$$
\log \left(q_{e}-q_{t}\right)=\log q_{e}-\frac{k_{1, a d s}}{2.303} t
$$

where $\mathrm{q}_{\mathrm{e}}$ is the amount of dye adsorbed $(\mathrm{mg} / \mathrm{g})$ at equilibrium, $\mathrm{q}_{\mathrm{t}}$ is the amount of dye adsorbed $(\mathrm{mg} / \mathrm{g})$ at time $\mathrm{t}(\mathrm{min})$ and $\mathrm{k}_{1}$ is the pseudo-first order rate constant $\left(\mathrm{min}^{-1}\right)$ of adsorption. The graph between $\log \left(\mathrm{q}_{\mathrm{e}}-\mathrm{q}_{\mathrm{t}}\right)$ versus $\mathrm{t}$ was plotted in order to calculate the constants. The different values of $\mathrm{k}_{1}, \mathrm{q}_{\mathrm{e}}$ and correlation coefficient at different concentrations were calculated from these plots and are given in Table-2.

The linear form of pseudo-second order equation is given as:

$$
\frac{\mathrm{t}}{\mathrm{q}}=\frac{1}{\mathrm{k}_{2, \mathrm{ads}} \mathrm{q}_{\mathrm{e}}^{2}}+\frac{1}{\mathrm{q}_{\mathrm{e}}} \mathrm{t}
$$

where $\mathrm{q}_{\mathrm{e}}$ and $\mathrm{q}$ are the amounts of the dye adsorbed by the algal biomass $(\mathrm{mg} / \mathrm{g})$ at equilibrium and time $\mathrm{t}$, respectively and $\mathrm{k}_{2}\left(\mathrm{~g} \mathrm{mg}^{-1} \mathrm{~min}^{-1}\right)$ is the rate constant of second order adsorption. $\mathrm{q}_{\mathrm{e}}$ and $\mathrm{k}_{2}$ can be computed from the slope and intercept obtained from the plots of $\mathrm{t} / \mathrm{q}$ versus $\mathrm{t}$.

The mathematical formula for the intraparticle diffusion rate constant can be expressed as:

$$
\mathrm{q}_{\mathrm{t}}=\mathrm{k}_{\mathrm{id}} \mathrm{t}^{1 / 2}
$$

where $\mathrm{q}_{\mathrm{t}}$ is the amount of methyl orange adsorbed per unit mass of adsorbent $(\mathrm{mg} / \mathrm{g})$ at time $\mathrm{t}$ and $\mathrm{k}_{\mathrm{id}}$ the intra-particle diffusion rate constant $\left(\mathrm{mg} / \mathrm{g} \mathrm{min}{ }^{-1 / 2}\right)$. According to this model, the plot of uptake should be linear if intraparticle diffusion is involved in the adsorption process and if these lines pass through the origin then intraparticle diffusion is the rate contro-

\begin{tabular}{|c|c|c|c|c|c|c|c|c|c|}
\hline \multirow{2}{*}{$\begin{array}{c}\text { Initial dye } \\
\text { concentration } \\
(\mathrm{mg} / \mathrm{L})\end{array}$} & \multicolumn{4}{|c|}{ First-order model } & \multicolumn{3}{|c|}{ Second-order model } & \multicolumn{2}{|c|}{ Intra-particle model } \\
\hline & $\begin{array}{c}\mathrm{q}_{\mathrm{e}}(\exp ) \\
(\mathrm{mg} / \mathrm{g})\end{array}$ & $\begin{array}{c}\mathrm{K}_{1}\left(\times 10^{-3}\right. \\
\mathrm{min}^{-1)}\end{array}$ & $\begin{array}{l}\mathrm{q}_{\mathrm{e}}(\mathrm{cal}) \\
(\mathrm{mg} / \mathrm{g})\end{array}$ & $\mathrm{R}^{2}$ & $\begin{array}{c}\mathrm{K}_{2} \times 10^{-3} \\
(\mathrm{~g} / \mathrm{mg} / \mathrm{min})\end{array}$ & $\begin{array}{l}\mathrm{q}_{\mathrm{e}}(\mathrm{cal}) \\
(\mathrm{mg} / \mathrm{g})\end{array}$ & $\mathrm{R}^{2}$ & $\begin{array}{c}\mathrm{K}_{\mathrm{id}}(\mathrm{mg} / \mathrm{g} \\
\left.\min ^{0.5}\right)\end{array}$ & $\mathrm{R}^{2}$ \\
\hline 100 & 70.46 & 46.06 & 48.383 & 0.916 & 0.1720 & 81.96 & 0.999 & 1.456 & 0.902 \\
\hline 200 & 93.93 & 91.12 & 66.374 & 0.917 & 0.7170 & 91.74 & 0.998 & 2.269 & 0.913 \\
\hline
\end{tabular}
lling step [36].

Table-2 represents the results of the adsorption kinetics of dye and rate of adsorption were found to confirm to pseudosecond-order kinetics. It was observed that the calculated value of $\mathrm{q}_{\mathrm{e}}$ was close to the experimental value of $\mathrm{q}_{\mathrm{e}}$ for pseudo-

TABLE-2

SUMMARY OF ADSORPTION DATA EVALUATED BY DIFFERENT KINETIC MODELS FOR Oscillatoria SPECIES 
second order kinetics, with good correlation at two different concentrations.

Desorption studies: For desorption studies three different eluents ( $\mathrm{HCl}, \mathrm{NaOH}$ and EDTA) were used and it was observed that $\mathrm{HCl}$ was most effective among all the desorbents studied. More than $75 \%$ of methyl orange was desorbed from the adsorbent in the first cycle using $\mathrm{HCl}$ [37]. Adsorption capacity did not noticeably change (only a maximum of $15-20 \%$ change was observed with the tested alga) during the repeated adsorption-desorption operations. Adsorption capacity was as high as $47.50 \mathrm{mg} / \mathrm{g}$ till the third cycle, which later reduced for the $4^{\text {th }}$ and the $5^{\text {th }}$ cycle (Fig. 7). These results showed that the adsorbent could be repeatedly used in methyl orange adsorption studies without significant losses in initial adsorption capacity.

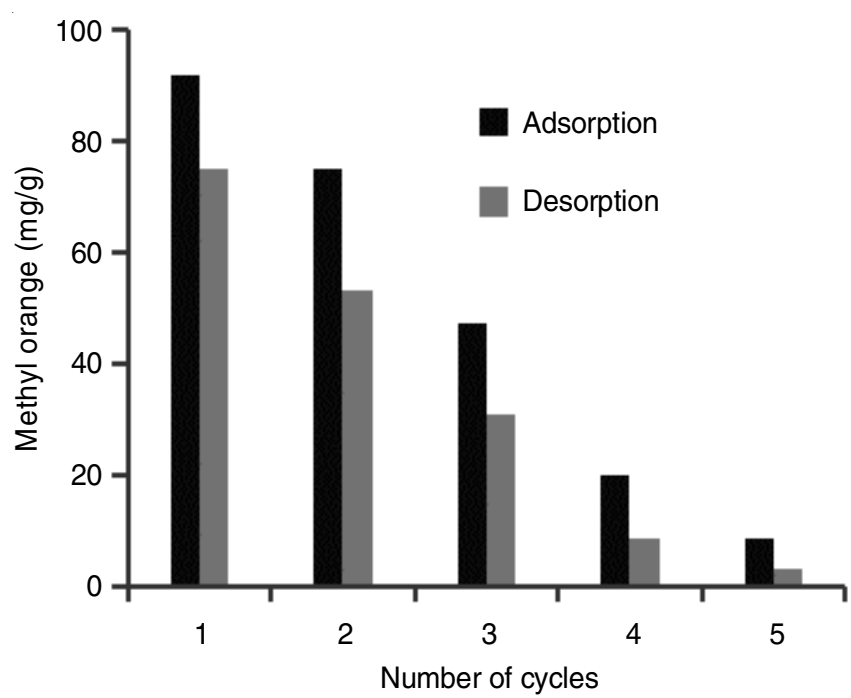

Fig. 7. Adsorption/desorption cycles of Oscillatoria species biomass using $\mathrm{HCl}$ as an eluent

\section{Conclusion}

The results of this study indicated that Oscillatoria species is an efficient adsorbent for the removal of methyl orange from synthetic wastewater. The experimental evidences showed the strong effect of the operating variables on the adsorption performance of Oscillatoria species. The maximum methyl orange adsorption capacity has been found to be $98.03 \mathrm{mg} / \mathrm{g}$ at an algal dose of $5 \mathrm{~g} / \mathrm{L}$ in $80 \mathrm{~min}$ of contact time with optimum pH 4 at $318 \mathrm{~K}$. The equilibrium data has been analyzed using various adsorption isotherms and the results showed that the experimental data were correlated reasonably well by the Langmuir adsorption isotherm. Thermodynamic parameters indicated that the adsorption of methyl orange dye onto the algal biomass was feasible, spontaneous and endothermic under studied conditions. The kinetic studies of methyl orange adsorption on Oscillatoria species were performed based on pseudofirst order, Pseudo-second order and intraparticle diffusion rate mechanism and the results indicate that alga followed the pseudo-second order rate expression. The interactions of the dye and the functional groups on the algal cell wall surface were confirmed by FTIR analysis, which specify the participation of $-\mathrm{COOH},-\mathrm{OH}$ and $-\mathrm{NH}_{2}$ functional groups.

\section{CONFLICT OF INTEREST}

The authors declare that there is no conflict of interests regarding the publication of this article.

\section{REFERENCES}

1. S. Chakraborty, S. De, J.K. Basu and S. DasGupta, Desalination, 174, 73 (2005);

https://doi.org/10.1016/j.desal.2004.08.040.

2. G. Crini, Bioresour. Technol., 97, 1061 (2006); https://doi.org/10.1016/j.biortech.2005.05.001.

3. S. Rasalingam, R. Peng and R.T. Koodali, J. Nanomater, 2014, Article ID 617405 (2014); https://doi.org/10.1155/2014/617405.

4. M. Arami, N.Y. Limaee, N.M. Mahmoodi and N.S. Tabrizi, J. Hazard. Mater, 135, 171 (2006);

https://doi.org/10.1016/j.jhazmat.2005.11.044.

5. K. Kabra, R. Chaudhary and R.L. Sawhney, Ind. Eng. Chem. Res., 43, 7683 (2004);

https://doi.org/10.1021/ie0498551.

6. A. Fernandes, A. Morao, M. Magrinho, A. Lopes and I. Goncalves, Dyes Pigments, 61, 287 (2004); https://doi.org/10.1016/i.dyepig.2003.11.008

7. A. Akbari, J.C. Remigy and P. Aptel, Chem. Eng. Process., 41, 601 (2002); https://doi.org/10.1016/S0255-2701(01)00181-7.

8. K. Ravikumar, S. Krishnan, S. Ramalingam and K. Balu, Dyes Pigments, 72, 66 (2007);

https://doi.org/10.1016/j.dyepig.2005.07.018

9. M. Rafatullah, O. Sulaiman, R. Hashim and A. Ahmad, J. Hazard. Mater, 177, 70 (2010); https://doi.org/10.1016/j.jhazmat.2009.12.047.

10. A.A. Jalil, S. Triwahyono, S.H. Adam, N.D. Rahim, M.A. Aziz, N.H.H. Hairom, N.A.M. Razali, M.A.Z. Abidin and M.K.A. Mohamadiah, J. Hazard. Mater, 181, 755 (2010); https://doi.org/10.1016/j.jhazmat.2010.05.078

11. Z. Velkova, G. Kirova, V. Gochev, V. Kafadarova and M. Stoytcheva, Scientific Works of University of Food Technologies, LXI, 546 (2014).

12. M. Kousha, E. Daneshvar, M.S. Sohrabi, M. Jokar and A. Bhatnagar, Chem. Eng. J., 192, 67 (2012); https://doi.org/10.1016/j.cej.2012.03.057.

13. E. Daneshvar, M. Kousha, M.S. Sohrabi, A. Khataee and A. Converti, Chem. Eng. J., 195, 297 (2012); https://doi.org/10.1016/j.cej.2012.04.074

14. K.S. Bharathi and S.T. Ramesh, Appl. Water Sci., 3, 773 (2013); https://doi.org/10.1007/s13201-013-0117-y.

15. M. Benadjemia, L. Millière, L. Reinert, N. Benderdouche, L. Duclaux, Fuel Process. Technol., 92, 1203 (2011); https://doi.org/10.1016/j.fuproc.2011.01.014.

16. H.N. Al-Ani, Asian J. Chem., 30, 633 (2018) https://doi.org/10.14233/ajchem.2018.21063.

17. H.W. Kwak, Y. Hong, M.E. Lee and H.J. Jin, Int. J. Biol. Macromol, 120(Part A), 906 (2018); https://doi.org/10.1016/j.ijbiomac.2018.08.116.

18. D.L. Pavia, G.M. Lampman and G.S. Kaiz, Introduction to Spectroscopy: A Guide to Students of Organic Chemistry, W.B. Saunders Company (1987).

19. S. Sagar and A. Rastogi, J. Appl. Chem., 6, 374 (2017).

20. S. Sagar and A. Rastogi, Asian J. Res. Chem., 11, 778 (2018); https://doi.org/10.5958/0974-4150.2018.00137.2.

21. I.D. Mall, V.C. Srivastava and N.K. Agarwal, Dyes Pigments, 69, 210 (2006); https://doi.org/10.1016/j.dyepig.2005.03.013

22. T.K. Saha, N.C. Bhoumik, S. Karmaker, M.G. Ahmed, H. Ichikawa and Y. Fukumori, J. Water Resource Prot., 2, 898 (2010); https://doi.org/10.4236/jwarp.2010.210107.

23. C. Namasivayam and D. Kavitha, Dyes Pigments, 54, 47 (2002); https://doi.org/10.1016/S0143-7208(02)00025-6.

24. T. Subarioglu and I.S. Bilkay, J. Sci. Ind. Res., 68, 1075 (2009).

25. C. Smaranda, D. Bulgariu and M. Gavrilescu, Environ. Eng. Manage. J., 8, 1391 (2009); https://doi.org/10.30638/eemj.2009.203. 
26. I. Langmuir, J. Am. Chem. Soc., 40, 1361 (1918); https://doi.org/10.1021/ja02242a004.

27. H. Freundlich, Z. Phys. Chem., 57U, 385 (1907); https://doi.org/10.1515/zpch-1907-5723.

28. M.J. Temkin and V. Pyzhev, Acta Physicochem. URSS, 12, 217 (1940).

29. M.M. Dubinin, Chem. Rev., 60, 235 (1960); https://doi.org/10.1021/cr60204a006.

30. R. Sivaraj, C. Namasivayam and K. Kadirvelu, Waste Manage., 21, 105 (2001);

https://doi.org/10.1016/S0956-053X(00)00076-3.

31. E.R. Alley, Water Quality Control Handbook, McGraw-Hill Education: London, p. 125 (2000).
32. A.R. Khataee, F. Vafaei and M. Jannatkhah, Int. Biodeter. Biodegr, 83, 33 (2013);

https://doi.org/10.1016/j.ibiod.2013.04.004.

33. S. Lagergren, K. Sven. Vetensk. Akad. Handl., 24, 1 (1898).

34. Y.S. Ho and G. McKay, Process Biochem., 34, 451 (1999); https://doi.org/10.1016/S0032-9592(98)00112-5.

35. S.J. Allen, G. Mckay and K.Y.H. Khader, Environ. Pollut., 56, 39 (1989); https://doi.org/10.1016/0269-7491(89)90120-6.

36. W.J. Weber and J.C. Morris, J. Sanit. Engrg. Div., 89, 31 (1963).

37. H. Katircioglu, B. Aslim, A. Rehber Türker, T. Atici and Y. Beyatli, Bioresour. Technol., 99, 4185 (2008); https://doi.org/10.1016/j.biortech.2007.08.068. 